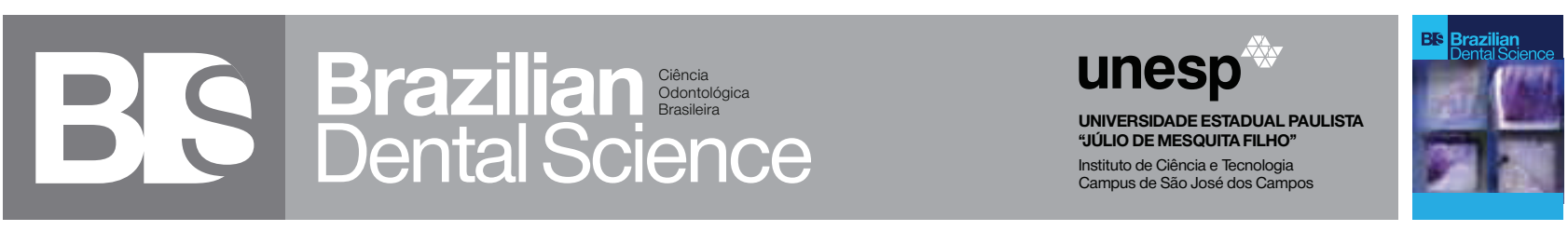

\title{
Dentinal Hypersensitivity: pre-hybridization as an alternative treatment
}

Hipersensibilidade dentinária: pré-hibridização como um tratamento alternativo

Clóvis PAGANI ${ }^{1}$, Fernanda Alves FEITOSA ${ }^{1}$, Stella Renata Machado Silva ESTEVES ${ }^{1}$,Geraldo Marques de MIRANDA ${ }^{1}$, Débora Pinto ANTUNES $^{1}$, Rodrigo Furtado de CARVALHO ${ }^{1}$

1 - Institute of Science and Technology - UNESP - Univ Estadual Paulista - School of Dentistry - São José dos Campos - SP - Brazil.

\section{ABSTRACT}

Dentinal hypersensitivity may occur after the dentine exposure because of indirect restoration preparations. Either to avoid or decrease postoperative discomfort, dentinal adhesives have been used to protect the exposed dentine. This technique is called pre-hybridization. Notwithstanding, despite of the clinical use, there still exist controversies on its efficacy and the most adequate material and protocol to execute it. Objective:This review study aimed to discuss the concepts involving the pre-hybridization based on the most important papers published from 2002 to date, indexed at the following databases: SciELO, MEDLINE and Pubmed. Methods: The following keywords were applied in the searching: pre-hybridization, tooth hypersensitivity and their possibilities (e.g.: dentinal pre-hybridization, dentinal hypersensitivity, hypersensitivity treatment). Only review and original research studies were selected. Efforts to identify comparative, controlled clinical studies as well as meta-analysis studies on hypersensitivity and dentinal pre-hybridization were made. Results: Based on the review conducted, it was possible to highlight that the self-conditioning adhesives have been the first choice for pre-hybridization procedures. Conclusion: However, the literature still lacks on determining a consolidated protocol and the clinical effectiveness of this procedure.

\section{RESUMO}

A hipersensibilidade dentinária pode ocorrer quando há exposição da dentina após preparos dentários para restaurações indiretas. Para evitar ou minimizar desconfortos pós-operatórios, os adesivos dentinários têm sido utilizados para proteger a dentina exposta. Esta técnica é denominada préhibridização. Apesar da utilização clínica, ainda existem controvérsias sobre a eficácia, o material e o protocolo mais adequado para realizá-la. Objetivo: Esta revisão tem como objetivo discutir os conceitos que envolvem a pré-hibridização, baseando-se nos artigos mais relevantes publicados (2002 até a data atual), indexados nas bases de dados da SciELO, MEDLINE e Pubmed. Método: Para a pesquisa foram utilizadas as seguintes palavras-chave: préhibridização, hipersensibilidade dental e variáveis (ex.: pré-hibridização dentinária, hipersensibilidade dentinária, tratamento de hipersensibilidade). Foram selecionadas as referências do tipo revisão e artigos de pesquisa originais. Foram feitos esforços para identificar estudos sobre tratamentos clínicos comparativos, controlados e estudos de meta-análise sobre a hipersensibilidade e a pré-hibridização dentinária. Resultado: Baseado na revisão realizada é possível destacar os adesivos autocondicionantes como a primeira escolha para os procedimentos de pré-hibridização. Conclusão: Porém, a literatura ainda não apresenta um protocolo consolidado e as pesquisas clínicas que estudam a eficiência desta técnica são limitadas.

\section{PALAVRAS-CHAVE}

Pré-hibridização; hipersensibilidade dentinária; Adesivos.

Pre-hybridization; Dentinal hypersensitivity; Adhesives. 


\section{INTRODUCTION}

$\mathrm{M}$

any times, indirect restoration preparations expose the dentine and may lead to post-operative discomforts, such as dentinal hypersensitivity [1]. This has been one of the most reported clinical problems after the final cementation of indirect restorations [2-4]. The dentinal fluid is within the dentinal tubules and contains a great amount of water and odontoblastic processes [5]. These later directly link the dentine to the pulp accounting for the sensitivity felt after the preparations [5].

The hydrodynamic theory is the most accepted rationale to explain dentinal hypersensitivity, claiming that the sensitivity is justified by minimal movements within the dentinal tubules [6]. These movements push the odontoblasts by mechanically, thermally, or chemically stimulating the adjacent nerve fibers [7].

The tooth preparations comprising wear greater than 2 to $3 \mathrm{~mm}$ generally expose the dentine structure [8]. The post-operative sensitivity reported by patients in the ending of the preparation may be either exacerbated or initiated by several factors: use of old burs and points; inadequate use of points and burs; lack of irrigation; application of irritating dental materials [3]; and presence of unsatisfactory margins of the provisional crowns [9].

Doubts still exist on which technique would be the most adequate approach either to eliminate or to decrease the post-operative sensitivity [10-12]. So far, none predictable treatment which completely eliminates the long-term pain perception has been defined as the therapeutic "gold standard" [13]. Among the several methods employed, the prehybridization is characterized by the application of either an adhesive system or a flowable resin immediately after the preparation aiming to seal and protect the tooth structure [14-16]. The rationale behind this technique is that the tooth freshly prepared is more permeable [16] therefore becoming more susceptible to irritating agents [9].
Also, the pre-hybridization has been reported to increase the bond strength values of the indirect restorations [17-21], decrease the risk of bacterial contamination by oral fluids, and prevent the post-operative hypersensitivity, therefore enabling greater comfort and longer durability of the restoration [22]. Notwithstanding, despite of its clinical use, there still exist controversies on its efficacy and the most adequate material and protocol to execute it. This review study aimed to discuss the concepts involving pre-hybridization procedure.

\section{MATERIAL AND METHODS}

This literature review study relied on the most relevant papers published from 2002 to date, indexed in the following databases: SciELO, MEDLINE and Pubmed. The searching occurred from January to April of 2013 with the following keywords either in English or Spanish language: pre-hybridization, dental hypersensitivity and their possibilities (e.g.: dentinal pre-hybridization, dentinal hypersensitivity, hypersensitivity treatment). Only review and original research studies were selected. Efforts to identify comparative, controlled clinical studies as well as metaanalysis studies on hypersensitivity and dentinal pre-hybridization were made.

\section{Hydrodynamic theory}

Therationalebehind the theoriesexplaining the mechanism of dentinal hypersensitivity is closely related to the morphology and histology of the dentin-pulp complex. The tooth is a complex structure composed by organic and mineralized tissues. These protect the pulp formed by blood vessels, conjunctive tissue and nerve tissue, which accounts for mediating the pain [23].

The dentine is composed by a collagen matrix filled with small apatite crystals, rich in carbonates but less calcified than enamel. These crystals are cylindrical and parallelly dispersed forming the tubules [24]. The odontoblastic 
processes fill in the tubules communicating with the pulp, resulting in the so-called dentinepulp complex [24]. As the dentinal tissue does not contain nerve cells, it is expected that the presence of aggressor agents do not result in pain stimuli [25]. Notwithstanding, in many cases a sensitive response does occur, socalled hypersensitivity [25]. Teeth affected by hypersensitivity exhibit a greater number and diameter of the tubules than non-sensitive teeth $[26,27]$.

The sensorial system of the pulp seems to be well adapted to sign potential damage to the tooth [28]. Ultra-structural studies have confirmed the physical proximity of the sensorial nerves to odontoblasts [28]. The pulp is richly innervated and contains both myelinated and unmyelinated nerve fibers [3]. Most part of the nerve fibers penetrates through the apical foramen, although a small number may enter through accessory canals [3]. The nerves of the pulp are composed of primary afferent fibers accounting for the pain transmission as well as efferent sympathetic fibers modulating its microcirculation [3].

Studies have been conducted to understand better the painful response $[29,30]$, and they demonstrated that the explication most accepted to date which better justifies the dentinal sensitivity is the hydrodynamic theory. This theory postulates that the fluids within the dentinal tubules undergo agitation after thermal, physical and osmotic changes leading to neural discharges through the stimulus of mechanoreceptors. This hydrodynamic movement generates an intratubular pressure change in addition to the excitation of the nerve terminations of the pulp, starting the painful sensation. To define this theory, the authors reported the process of painful perception and stimulus transmission within the dentinal tubules based on the concept that the fluids within the dentinal tubules would be in constant movement [7].

To support the theory, the authors conducted tests with dehydrating, thermal and osmotic stimuli [7]. To observe the dehydration effect, the exposed dentin was dried resulting in the movement of the fluids within the tubules aiming to maintain the humidity of the area [6,7]. This interaction would lead to the stimulation of the odontoblastic processes and the nerve receptors $[6,7]$. To verify the effect of the thermal stimulus, the dentine was exposed to varied temperatures showing that the variation of the thermal expansion coefficient between the dentinal fluid and the tubules led to the movement of the fluid within them $[6,7]$. Cold application resulted in contraction effect by exerting pressure on the sensitive nerve terminations of the pulp [6,7]. The movement of the fluid within the dentinal tubules was also related to the maintenance of the osmotic balance in the presence of acidic, salty, and sweet food $[6,7]$. The fluid tends to migrate towards outside the tubules, from the less to the most concentrated medium which also stimulates the nerve terminations causing pain $[6,7]$.

\section{Pre-hybridization techniques}

Conceptually, there are two main approaches for controlling dentinal hypersensitivity: 1) to prevent or decrease the nerve transmission; 2) to occlude the dentinal tubule. This latter represents a large number of treatment approaches [7]. The rationale behind the use of adhesive systems relies on the principle of sealing the dentinal tubules so that the transmission of the hydrodynamic stimuli towards the pulp complex is avoided. The deposition of a thin coating pellicle by applying the dentinal adhesive creates an artificial hybrid layer which seals the open tubules [12,31,32].

The dentinal sealing technique has different classifications and definitions $[14,15]$. The first researchers to develop this technique, in 1990, named it "resin coating" [14,15]. At that time, a low viscosity resin with low modulus of elasticity was employed after the application and light-curing of the adhesive system $[14,15]$.

A variation of the technique described in 1996, so-called "dual bonding technique", 
comprised two stages [33]. At the first stage, the adhesive system is applied and light-cured immediately after the ending of the tooth preparation and previously to the impression procedure [33]. At the second stage, prior to the final cementation of the indirect restoration, a new layer of the bonding agent is applied without its light-curing [33]. This is obtained after the cementation [33]. It is believed that the bonding agent layer together with the luting agent may interfere on the adaptation of the indirect restoration [33].

Both techniques may undergo little modifications [34,35]. Whenever possible, absolute isolation is recommended [22], aiming to protect the dentin from the bacterial contamination and material remnants which could result in post-operative sensitivity [9].

Some studies advised the use of a layer of water-soluble glycerin gel prior to the last photoactivation [36,37]. Its function is to inhibit the oxygen layer therefore making viable the photoactivation [36,37]. Also, it prevents the interaction between the dentinal adhesive and the impression material which frequently occurs between polyether- and polyvinyl-based materials $[17,29,38]$. The application of the water-soluble gel is essential to achieve the complete curing of the impression material $[17,29,38]$. A study in which the gel was not applied, obtained $100 \%$ of impression failures because of the interaction of the adhesive system with the impression material [20]. The photoactivation must be executed for $5 \mathrm{~s}$ before the gel application and for $30 \mathrm{~s}$ after it [36]. However, studies have advocated either $20 \mathrm{~s}$ prior to and $10 \mathrm{~s}$ of photoactivation after the gel application [22] or $10 \mathrm{~s}$ before and after it $[37,38]$. Then, the set must be washed aiming to remove the glycerin layer. After that, the bonding agent excess is removed from the preparation margin with the aid of either instruments or low-speed burs to avoid the misadaptation of the indirect restoration $[17,37]$.
The pre-hybridization of the dentine can improve the bond strength if the surface is treated by sandblasting with aluminum oxide particles associated with $37 \%$ phosphoric acid, followed by the application of a second layer of bonding agent [39].

The protocol for employing conventional adhesive systems is: apply $36 \%$ phosphoric acid, by varying the time of etching between 5 and $30 \mathrm{~s}$ (time used in the cases with enamel remnants) [17]; wash for $60 \mathrm{~s}$ and dry for $5 \mathrm{~s}$ [12,37]; apply desensitizing agent for $30 \mathrm{~s}$, twice $[12,37]$; apply the primer agent followed by an air jet for $20 \mathrm{~s}$ and the bonding agent application $[37,38]$. Some recent studies observed that the desensitizing agent was removed without undermining the technique effectiveness [17,20].

With the use of self-etching adhesive systems in which the acid and the primer agent is within the same flask, the number of the aforementioned steps are reduced, comprising the bonding agent application followed by gently air drying if this is not within the same flask $[9,40]$.

The pre-hybridization has the advantage of not only protecting the dentine and eliminating the dentinal hypersensitivity immediately after the cementation $[16,22]$ but also for a period of up to 1 month after the cementation [22]. Additionally, this technique contributes for the significantly highest shear strength $[18,9,21]$ and microtensile values $[17,41]$ for a period of up to 2 weeks [35]. Comparing this technique with that employed prior to cementation, prehybridization procedure with both self-etching and conventional adhesive systems improved the microtensile strength $[17,34,41]$.

Considering the great variety of approaches within the literature, there is no consensus on the pre-hybridization steps. There is no defined protocol to be adopted. Do or do not execute the photoactivation of the last bonding agent layer, the number of layers to be 
applied, and the adhesive system stability after the impression procedure are frequent doubts. The major problem to be considered is that the adhesive substrate is no longer the dentine but the adhesive surface [39].

\section{Adhesive systems used}

The choice of the adhesive system to be used in the pre-hybridization procedure should take into consideration some of their inherent specificities $[42,43]$. The procedure employing the conventional adhesive system is executed by etching with phosphoric acid $[42,43]$, followed by washing and air drying and application of the primer and bonding agent $[42,43]$. This system is commonly sold in three separated flasks (acid, primer and bonding agent); yet, the primer and bonding agent can be within one flask $[44,45,46]$. On the other hand, the selfetching adhesive systems are sold either within one single flask containing the acid, primer and bonding agents or within two flasks - one flask containing the self-etching primer agent, and the other flask containing the bonding agent [43]. This adhesive system was developed to eliminate the etching, washing and drying steps which are sensitive stages depending on the operator. The easiness of this system considerably simplified the procedure [43]. The self-etching systems are less sensitive to the technique, consequently, there is a smaller chance of error which may contribute to post-operative sensitivity [10,47-49].

Ideally, the bonding agent polymerization should reduce the permeability of the exposed dentine. The resin tags formation within the dentinal tubules and the lateral anastomosis formed by the branches result in hybridization of the peritubular dentine [13]. Apparently, the permeability variations of the adhesively-sealed dentine depends greatly on the adhesive system employed [9,40,51,52]. A study conducted by Mithiborwala et al. 2013 [53] revealed a higher qualitative and quantitative capacity of penetration of the self-etching adhesive system than that of a conventional system. This fact would point out a tendency towards providing a smaller post-operative sensitivity [53].

Studies comparing self-etching adhesive with conventional systems regarding to the demineralization depth [19], hybridization thickness [35], effectiveness of resin tags lateral branch formation, and hybrid layer quality [40] have demonstrated that the self-etching adhesive system exhibited satisfactory behaviors.

The homogeneity of the bonding agent layer is highly important for pre-hybridization process. Both lack and excess of material would cause failures in either the sealing of the dentine freshly prepared [54] or the further adaptation of the indirect restoration [33]. Higher acidic self-etching systems tend to form thinner hybrid layers than those achieved by conventional systems, yet they have high bond strengths values [55].

Albaladejo et al. (2009) [56] found that the conventional systems exhibited a thicker hybrid layer with greater number of tags than that of the self-etching systems; however, in these latter, the hybrid layer thickness was continue and uniform [56]. Nakabayashi and Saimi (1996) [25] evaluated the reliability of self-etching systems on dentin and observed that the hybrid layer formation with this system is stable, of high quality and effective in cases of post-operative sensitivity. It is important to emphasize that different self-etching systems display different characteristics and behaviors. Perdigão et al. (2009) [53] highlighted the aggressive feature resulting from the $\mathrm{pH}$ differences therefore preferring the less acidic systems which are consequently less aggressive and with more adequate bonding characteristics [53]. Less acidic self-etching primers may help to reduce the hydrodynamic action through the dentinal tubules since these adhesive systems preserve the smear layer [53,57-59].

The conventional adhesive system increases both the dentine permeability and 
hydrodynamic action [50]. Two-step systems exhibited high percentage of hydrophilic monomers resulting in high degrees of permeability after the polymerization. These may increase nanoleakage and water passage through the hybrid layer $[60,61]$.

When the conventional system is employed, there is a higher superficial demineralization of the dentine and the monomers within the adhesive system are not capable of filling the large thicknesses created by this demineralization. This process is called non-infiltrated dentin zone which may account for nanoleakage by degrading the hybrid layer through hydrolysis [41,49]. The etching procedure not only enlarges the tubules, but also removes the smear layer that physically acts against the external stimuli $[12,59]$. Apparently, this process does not occur in the self-etching system because the dentine demineralization simultaneously occurs with the infiltration of the adhesive monomer [57].

In all studies evaluated, by comparing teeth which have or have not been submitted to pre-hybridization, the use of bonding agents improved the bond strength values of the former. However, the studies conducted so far are predominantly employing mechanical tests $[17,18,41]$. Consequently, the literature lacks on factual information regarding the decreasing in the post-operative sensitivity. Thus, further studies are necessary to evaluate the clinical medium- and long-term effectiveness of prehybridization procedure and to determine a protocol to be followed.

\section{CONCLUSION}

Few studies focused on the procedures to avoid hypersensitivity. The self-etching adhesive systems are emphasized as the first choice for pre-hybridization procedures. However, the literature still lacks on determining both a consolidated protocol and the clinical effectiveness of this procedure.

\section{REFERENCES}

1. Schmidlin PR, Sahrmann P. Current management of dentin hypersensitivity. Clin Oral Invest. 2013 Mar;17(1):55-59.

2. Helvey GA. Adhesive dentistry: the development of immediate dentin sealing/selective etching bonding technique. Compend Contin Educ Dent. 2011 Nov-Dec;32(9):22-38.

3. Parolia A, Kundabala M, Mohan M. Management of dentinal hypersensitivity: a review.J Calif Dent Assoc. 2011 Mar;39(3):16779.

4. Briso ALF, Mestrener SR, Delício G, Sundfeld RH, Bedran-Russo AK, de Alexandre RS, et al. Clinical assessment of postoperative sensitivity in posterior composite restorations. Oper Dent. 2007 Set-0ct;32(5):421-426.

5. Cilli R, Prakki A, Araújo PA, Pereira JC. Influence of glutaraldehyde priming on bond strength of an experimental adhesive system applied to wet and dry dentine. J Dent. 2009 Mar; 37(3):212-8.

6. Shiau HJ. Dentin hypersensitivity. J Evid Base Dent Pract. 2012 Sep;12(1):220-28.

7. Brannstrom M, Johnson G. Movements of the dentin and pulp liquids on application of thermal stimuli. An in vitro study. Acta Odontol Scand. 1970 Mar; 28(1):59-70.

8. Auschill TM, Koch CA, Wolkewitz M, Hellwig E, Arweiler NB. Occurrence and causing stimuli of postoperative sensitivity in composite restorations. Oper Dent. 2009 Jan-Feb;34(1):3-10.

9. Chersoni S, Suppa P, Grandini S, Goracci C, Monticelli F, Yiu C, Huang C, Prati C, Breschi L, Ferrari M, Pashley DH, Tay FR. In vivo and in vitro permeability of one-step self-etch adhesives. J Dent Res. 2004 Jun; 83: 459-64.

10. Casselli DSM, Martins LRM Postoperative sensitivity in class I composite resin restoration in vivo. J Adhes Dent. 2006 Feb;8(1):53-8.

11. De Munk J, Van Landuyt K, Peumans M, Poitevin A, Lam-brechts P Braem $M$, et al. A critical review of the durability adhesion to tooth tissue: methods and results. J Dent Res. 2005 Feb;84(2):118-32.

12. Swift EJ Jr, Ritter AV, Heymann HO, Sturdevant JR, Wilder AD Jr. 36-month clinical evaluation of two adhesives and microhybrid resin composites in Class I restorations. Am J Dent. 2008 Jun;21(3):148-52.

13. Schmidlin PR, Sahrmann P. Current management of dentin hypersensitivity. Clin Oral Invest. 2013 Mar;17(1):55-9.

14. Kitasako Y, Burrow MF, Nikaido T, Tagami J. Effect of resin-coating technique on dentin tensile bond strengths over 3 years. J Esthet Restor Dent. 2002; 14(2): 115-22.

15. Nikaido T, Nakaoki Y, Ogata M, Foxton R, Tagamij. The resin-coating technique. Effect of a single-step bonding system on dentin bond strengths. J Adhes Dent. 2003 Feb; 5(4):293-300.

16. Andrade OS, Goes MF, Montes MA. Marginal adaptation and microtensile bond strenght of composite indirect restorations bonded to dentin treated with adhesive and low-viscosity composite. Dent Mat Mar. 2007; 23(3):279-87.

17. Duarte S, Freitas C, Saad J, Sadan A. The effect of immediate dental sealing on the marginal adaptation and bond strengths of total etch. J Dent Prosthet. 2009 Jul; 102(1):1-9. 
18. Lee Jl, Park SH. The effect of three variables on shear bond strength when luting a resin inlay to dentin. Oper Dent. 2009 MayJun; 34(3):288-92.

19. Choi YS, Cho IH. An effect of immediate dentin sealing on the shear Bond strength of resin cement to porcelain restoration. J Adv Prosthodont. 2010 Jun; 2(2):39-45.

20. Kitayama S, Nikaido T, Ikeda M, Alireza S, Miura H, Tagami J. Internal coating of zirconia restoration with silica-based ceramic improves bonding of resin cement to dental zirconia ceramic. BioMed Mat Eng. 2010;20:77-87.

21. Dalby R, Ellakwa A, millar B, Martin FE. Influence of immediate dentin sealing on the shear bond strenght of pressed ceramic luted to dentin with self-etch resin cement. Int J Dent. 2012;2012:310702.

22. Hu J, Zhu Q. Effect of immediate dentin sealing on preventive treatment for post cementation hypersensitivity. Int J Prosthod. 2010 Jan-Feb; 23(1):49-52.

23. Kinney JH, Marshall SJ, Marshall GW. The mechanical properties of human dentin: a critical review and re-evaluation of the denta literature. Crit Rev Oral Biol Med. 2003;14(1):13-29.

24. Holland GR. Morphological features of dentine and pulp related to dentine sensitivity. Arch Oral Biol. 1994;39(Suppl):3S-11S.

25. Nakabayashi, N. and Y. Saimi, Bonding to intact dentin. J Dent Res. 1996. 75(9): p. 1706-15.

26. Tay fR, Pashley $\mathrm{DH}$. Resin bonding to cervical sclerotic dentin: a review. J Dent. 2004 Mar;32(3):173-96.

27. Addy M. Tooth brushing, tooth wear and dentine hypersensitivityare they associated? Int Dent J. 2005;55(4 Suppl 1):261-7.

28. Carda C, Peydro A. Ultrastructural patterns of human dentinal tubules, odontoblasts processes and nerve fibers. Tissue Cell. 2006 Apr;38(2):141-50

29. Ladalardo TC, Pinheiro A, Campos RA, Brugnera Junior A, Zanin F, Albernaz PL. Laser therapy in the treatment of dentine hypersensitivity. Braz Dent J. 2004; 15(2):144-50.

30. Akpata ES, Behbehani J. Effect of bonding systems on postoperative sensitivity from posterior composites. Am J Dent. 2006 Jun;19(3);151-4.

31. Duran I, Sengun A. The long-term effectiveness of five current desensitizing products on cervical dentine sensitivity. J Oral Rehabil. 2004 Apr ;31(4):351-6.

32. Pol DG, Jonnala J, et al. current strategy in the management of dentinal hypersensitivity. J Indian Dent Assoc. 2011;5(6):746-9.

33. Jayasooriya PR, Pereira PN, Nikaido T, Burrow MF, Tagami J. The effect of a "resin coating" on the interfacial adaptation of composite inlays. Oper Dent. 2003 Jan-Feb;28:28-35.

34. Magne P. Immediate denting sealing : a fundamental procedure for indirect bonded restorations. J Esthet Restor Dent. 2005;17(3):14454.

35. Magne P, So WS, Cascione D. Immediate dentin sealing supports delayed restoration placement. J Prosthet Dent. 2007 Sep;98(3):166-74.

36. Magne P, Nielsen B. Interactions between impression materials and immediate dentin sealing. J Prosthet Dent. 2009 Nov;102(5):298305.

37. Magne P,Douglas WH. Porcelain veneers: dentin bonding optimization and biomimetic recovery of the crown. Int JProsthod. 1999 Mar-Apr;12(2):111-21.
38. Cohen RG, Razzano VM. Immediate Dentin Sealing using an Antibacterial Self Etching Bonding System. Pract Proced Aesthet Dent. 2006 0ct;18(9):561-5.

39. Dillenburg AL, Soares CG, Paranhos MP, Spohr AM, Loguercio AD, Burnett LH Jr. Microtensile bond strength of prehybridized dentin storage time and surface treatment effects. J Adhes Dent. 2009 Jun;11(3):231-7.

40. Gregoire G, Joniot S, Guignes P, Millas A. Dentin permeability: self-etching and one-bottle dentin bonding systems. J Prosthet Dent. 2003 Jul; 90: 42-49.

41. Paul SJ, Welter DA, Ghazi M, Pashley D. Nanoleakage at the dentin adhesive interface vs microtensile bond strength. Oper Dent. 1999 May-Jun; 24(3): 181-8.

42. Chermont AB, Carneiro KK, Lobato MF, Machado SMM, Souza Junior MHS. Clinical evaluation of postoperative sensitivity using self-etching adhesives containing glutaraldehyde. Braz Oral Res. 2010 Jul-Sep;24(3):349-54

43. Perdigão J, Dutra-Corrêa M, Anauate-Netto C, Castilhos N, Carmo ARP, Lewgoy HR, Amore R, Cordeiro HJD. Two-year clinical evaluation of self-etching adhesives in posterior restorations. J Adhes Dent. 2009 Apr;11(2);149-59.

44. Unemori M, Matsuya Y, Hyakutake H, Matsuya S, Goto Y, Akamine A. Long-term follow-up of composite resin restorations with selfetch adhesives. J Dent. 2007;35:535-40.

45. Kaurani M, Bhagwat SV. Clinical evaluation of postoperative sensitivity in composite resin restorations using various liners. NY State Dent J. 2007 Mar;73(2):23-9

46. Sauro S, Pashley DH, Montanari M, Chersoni S, Carvalho RM, Toledano M, Osorio R, Tay FR, Prati C. Effect of simulated pulpal pressure on dentin permeability and adhesion of self-etch adhesives. Dent Mater. 2007 Jun; 23: 705-713.

47. Toledano M, Cabello I, Yamauti M, Giannini M, Aguilera FS, Osorio E, Osorio R. Resistance to degradation of resin-dentin bonds produced by one-step self-etch adhesives. Microsc Microanal. 2012 Dec;18(6):1480-93.

48. Frankenberger $\mathrm{R}$, Kramer $\mathrm{N}$, Petschelt $\mathrm{A}$. Technique sensitivity of dentin bonding: effect of application mistakes on bond strength and marginal adaptation. Oper Dent. 2000 Jul-Aug: 25: 324-330.

49. De Munk J, Van Landuyt K, Peumans M, Poitevin A, Lam-brechts P, Braem $\mathrm{M}$, et al. A critical review of the durability adhesion to tooth tissue: methods and results. J Dent Res. 2005 Feb;84(2):118-32.

50. Pashley DH, Pashley EL, Carvalho RM, Tay FR. The effects of dentin permeability on restaurative dentistry. Dent Clin N Am. 2002 Apr; 46:211-45

51. Momoi Y, Akimoto N, Kida K, Yip KH, Kohno A. Sealing ability of dentin coating using adhesive resin systems. Am J Dent. 2003 Apr; 16: 105-111.

52. Alex $\mathrm{G}$. Is total-etch dead? Evidence suggests otherwise. Compend Contin Educ Dent. 2012 Jan;33(1):12-4, 16-22, 24-5; quiz 26, 38.

53. Mithiborwala S, Chaugule V, Munshi AK, Patil V. A comparison of the resin tag penetration of the total etch and the self-etch dentin bonding systems in the primary teeth: $A n$ in vitro study. Contemp Clin Dent. 2012 Apr;3(2):158-63.

54. Sahin C, Cehreli ZC, Yenigul M, Dayangac B. In vitro permeability of etch-and-rinse and self-etch adhesives used for immediate dentin sealing. Dent Mater J. 2012;31(3):401-8. Epub 2012 May 14. 
55. Van Meerbeek B, De Munck J, Yoshida Y, Inoue S, Vargas M, Vijay $P$, et al. Adhesion to enamel and dentin: current status and future challenges. Oper Dent. 2003 May-Jun;28(3):215-35.

56. Albaladejo A, Osorio R, Toledano M, Ferrari M. Hybrid layers of etch-and-rinse versus self-etching adhesive systems. Med Oral Patol Oral Cir Bucal. 2010 Jan 1;15(1):e112-8.

57. Oliveira SS, Marshall SJ, Hilton JF, Marshall GW. Etching kinetics of a self-etching primer. Biomaterials. 2002 0ct; 23: 4105-4112.

58. Olley Rc, Pilecki P, Hughes N, Jeffrey P, Austin RS, Moazzez R, et al. An in situ study investigating dentine tubule occlusion of dentifrices following acid challenge. J Dent 2012 Jul;40(7):585-93.
59. Schneider F, Hellwig E, Attin T. Influences of acid action and brushing abrasion on dentin protection by adhesive systems. Dtsch Zahnärztl Zeitschr. 2008;57:302-06.

60. Yui CKY, Hiraishi N, Chersoni S, Breschi L, Ferrari M, Prati C, et al. Single bottle adhesives behave as permeable membranes after polymerisation II. Differential permeability reduction with an oxalate desensitizer. J Dent. 2006 Feb;34(2):106-16.

61. Salz U, Mücke A, Zimmermann J, Tay FR, Pashley DH. PKa value and buffering capacity of acidic monomers commonly used in self-etch primers. J Adhes Dent. 2006 Jun;8(3):143-50.

\section{Rodrigo Furtado de Carvalho}

(Corresponding address)

Avenida Engenheiro Francisco José Longo, 777, Jardim São 